\title{
Sinorhizobium arboris sp. nov. and Sinorhizobium kostiense sp. nov., isolated from leguminous trees in Sudan and Kenya
}

\author{
Giselle Nick, ${ }^{1}$ Philippe de Lajudie, ${ }^{2,5}+$ Bertrand D. Eardly, ${ }^{3}$ \\ Sini Suomalainen, ${ }^{4}$ Lars Paulin, ${ }^{4}$ Xiaoping Zhang, ${ }^{1,6}$ Monique Gillis ${ }^{5}$ \\ and Kristina Lindström ${ }^{1}$
}

Author for correspondence: Giselle Nick. Tel: +3589708 59281. Fax: + 358970859322. e-mail: giselle.nick-maenpaa $($ helsinki.fi

\author{
1 Department of Applied \\ Chemistry and \\ Microbiology, PO Box 56, \\ Viikki Biocentre, FIN-00014 \\ University of Helsinki, \\ Finland \\ 2 Laboratoire de \\ Microbiologie des Sols, \\ ORSTOM BP 1386, Dakar, \\ Senegal \\ 3 Pennsylvania State \\ University, Berks Campus, \\ POB 7009, Reading, PA \\ 19610-6009, USA \\ 4 Institute of Biotechnology, \\ POB 56, Biocentre 1, \\ FIN-00014 University of \\ Helsinki, Finland \\ 5 Laboratorium voor \\ Microbiologie, Universiteit \\ Gent, K. L. \\ Ledeganckstraat, 35, \\ B-9000 Gent, Belgium \\ 6 Department of Applied \\ Microbiology, Sichuan \\ Agricultural University, \\ Yaan 625014, People's \\ Republic of China
}

\begin{abstract}
SDS-PAGE of total bacterial proteins was applied to the classification of $\mathbf{2 5}$ Sudanese and five Kenyan strains isolated from the root nodules of Acacia senegal and Prosopis chilensis. Twenty strains were also studied by multilocus enzyme electrophoresis (MLEE) and the whole 165 rRNA gene was sequenced from two strains representing the two major clusters. These results, together with the previously reported numerical taxonomy analysis, pulsed-field gel electrophoresis studies, DNA-DNA dot-blot hybridization, genomic fingerprinting using repetitive sequence-based PCR, DNA base composition analysis, DNA-DNA reassociation analysis, partial sequencing of the 165 rRNA gene and RFLP analysis of the amplified 165 rRNA gene, showed that all 30 strains belong to the genus Sinorhizobium. Two of the strains grouped with Sinorhizobium saheli and seven with Sinorhizobium terangae, while the rest did not cluster with any of the established species. The majority of the strains formed two phenotypically and genotypically distinct groups and we therefore propose that these strains should be classified as two new species, Sinorhizobium arboris sp. nov. and Sinorhizobium kostiense sp. nov.
\end{abstract}

Keywords: MLEE, SDS-PAGE, 16S rDNA sequencing, Sinorhizobium arboris, Sinorhizobium kostiense

\section{INTRODUCTION}

The bacteria that are able to form nitrogen-fixing nodules on leguminous plants and trees are currently divided into five genera, Azorhizobium, Brady-

†Present address: LSTM-ORSTOM/CIRAD-Forêt, Baillarget, BP 5035, 34032 Montpellier, France.

Abbreviations: $A C O$, aconitase; $A D K$, adenylate kinase; $E T$, electrophoretic type; G6P, glucose-6-phosphate dehydrogenase; HBD, hydroxybutyrate dehydrogenase; HEX, hexokinase; IDH, isocitrate dehydrogenase; IPO, indophenol oxidase; LAP, leucine aminopeptidase; MDH, NAD-malate dehydrogenase; MLEE, multilocus enzyme electrophoresis; PEP, leucylalanine peptidase; 6-PG, 6-phosphogluconate dehydrogenase; $\mathrm{PGI}$, phosphoglucose isomerase; PGM, phosphoglucomutase; rep-PCR, repetitive-sequence-based $P C R$.

The EMBL accession numbers for the 165 rRNA sequences of $S$. arboris HAMBI $1552^{\top}$ and S. kostiense HAMBI $1489^{\top}$ are 278204 and $\mathrm{Z78203}$. rhizobium, Mesorhizobium, Rhizobium and Sinorhizobium. Azorhizobium caulinodans, a stemnodulating species, is the only species of the genus Azorhizobium (Dreyfus et al., 1988). The bradyrhizobia, with species Bradyrhizobium elkanii (Kuykendall et al., 1992), Bradyrhizobium japonicum (Jordan, 1984) and Bradyrhizobium liaoningense (Xu et al., 1995), are root-nodulating but slow-growing bacteria. From the fast-growing rhizobia, the genus Sinorhizobium, with the species Sinorhizobium fredii (Scholla \& Elkan, 1984), Sinorhizobium meliloti (Jordan, 1984), Sinorhizobium saheli and Sinorhizobium terangae, was emended by de Lajudie et al. (1994) and recently Rome et al. (1996) described the newest member of this genus, Sinorhizobium medicae. The genus Mesorhizobium (Jarvis et al., 1997) consists of the species Mesorhizobium loti (Jarvis et al., 1982), 
Table 1. Strains used in this study

The strain numbers of Sudanese and Kenyan strains are according to Zhang et al. (1991), otherwise the original strain number or strain number as received is listed. ATCC, American Type Culture Collection, Manassas, VA, USA; CCBAU, Culture Collection of Beijing Agricultural University, Beijing, China; CFN, Centro de Investigación sobre Fijación de Nitrógeno, Universidad Nacional Aútonoma de México, Cuernavaca, Mexico; CIAT, Rhizobium Collection, Centro International de Agricultura Tropical, Cali, Colombia; HAMBI, Culture Collection of the Division of Microbiology, University of Helsinki, Helsinki, Finland; LMG, Collection of Bacteria of the Laboratorium voor Microbiologie, Ghent, Belgium; NZP, Culture Collection of the Department for Scientific and Industrial Research, Biochemistry Division, Palmerston North, New Zealand; ORS, ORSTOM Collection, Institut Français de Recherche Scientifique pour le Développement en Coopération, Dakar, Senegal; USDA, US Department of Agriculture, Beltsville, MD, USA. NK, Not known.

\begin{tabular}{|c|c|c|c|c|c|c|}
\hline \multirow[t]{2}{*}{ Strain } & \multicolumn{2}{|c|}{ Strain number } & \multirow[t]{2}{*}{ Cluster* } & \multirow[t]{2}{*}{ Host plant } & \multirow{2}{*}{$\begin{array}{c}\text { Geographical } \\
\text { origin } \dagger\end{array}$} & \multirow[t]{2}{*}{ Reference/source } \\
\hline & HAMBI & LMG & & & & \\
\hline \multicolumn{7}{|l|}{ Sinorhizobium arboris } \\
\hline $\mathrm{EO} 2$ & 1706 & 15624 & 11 & Acacia senegal & Sudan, EO & Zhang et al. (1991) \\
\hline EO3 & 1624 & - & 11 & Acacia senegal & Sudan, EO & Zhang et al. (1991) \\
\hline GB9 & 1700 & 15626 & 11 & Acacia senegal & Sudan, Kh & Zhang et al. (1991) \\
\hline GB10 & 1704 & 15629 & 11 & Acacia senegal & Sudan, $\mathrm{Kh}$ & Zhang et al. (1991) \\
\hline HAMBI 1396 & - & 14917 & 15 & Prosopis chilensis & Kenya & Zhang et al. (1991) \\
\hline TTR 3 & 1680 & 15621 & 11 & Prosopis chilensis & Sudan, Te & Zhang et al. (1991) \\
\hline TTR 22 & 1707 & - & 11 & Prosopis chilensis & Sudan, Ko & Zhang et al. (1991) \\
\hline TTR 33 & 1685 & 15637 & r 18 & Acacia senegal & Sudan, EF & Zhang et al. (1991) \\
\hline TTR $38^{\mathrm{T}}$ & $1552^{\mathrm{T}}$ & $14919^{\mathrm{T}}$ & 11 & Prosopis chilensis & Sudan, Ko & Zhang et al. (1991) \\
\hline \multicolumn{7}{|l|}{ Sinorhizobium kostiense } \\
\hline TTR 1 & 1679 & - & 1 & Prosopis chilensis & Sudan, Te & Zhang et al. (1991) \\
\hline TTR 2 & 1476 & - & 8 & Prosopis chilensis & Sudan, Te & Zhang et al. (1991) \\
\hline TTR 9 & 1482 & 14924 & 8 & Acacia senegal & Sudan, EF & Zhang et al. (1991) \\
\hline TTR 11 & 1484 & 15609 & 8 & Prosopis chilensis & Sudan, Ko & Zhang et al. (1991) \\
\hline TTR 12 & 1485 & 15610 & 8 & Prosopis chilensis & Sudan, Ko & Zhang et al. (1991) \\
\hline TTR $15^{\mathrm{T}}$ & $1489^{\mathrm{T}}$ & $15613^{\mathrm{T}}$ & 8 & Acacia senegal & Sudan, Ko & Zhang et al. (1991) \\
\hline TTR 18 & 1492 & 14926 & 8 & Prosopis chilensis & Sudan, Ko & Zhang et al. (1991) \\
\hline TTR 19 & 1493 & 14927 & r $1-9$ & Prosopis chilensis & Sudan, Kh & Zhang et al. (1991) \\
\hline TTR 27 & 1498 & 15615 & r 8 & Prosopis chilensis & Sudan, Ko & Zhang et al. (1991) \\
\hline TTR 31 & 1501 & - & 9 & Acacia senegal & Sudan, Ko & Zhang et al. (1991) \\
\hline TTR 34 & 1502 & 14911 & 8 & Acacia senegal & Sudan, Te & Zhang et al. (1991) \\
\hline TTR 36 & 1504 & 14929 & r $1-8$ & Prosopis chilensis & Sudan, Kh & Zhang et al. (1991) \\
\hline TTR 37 & 1505 & 14912 & 8 & Prosopis chilensis & Sudan, Ko & Zhang et al. (1991) \\
\hline \multicolumn{7}{|l|}{ Sinorhizobium sp. } \\
\hline HAMBI 1395 & - & 15632 & 12 & Prosopis chilensis & Kenya & Zhang et al. (1991) \\
\hline TTR 6 & 1480 & 14923 & 9 & Acacia senegal & Sudan, Ko & Zhang et al. (1991) \\
\hline TTR 7 & 1681 & 15634 & r 13 & Acacia senegal & Sudan, Ko & Zhang et al. (1991) \\
\hline TTR 28 & 1500 & - & 1 & Acacia senegal & Sudan, EF & Zhang et al. (1991) \\
\hline TTR 30 & 1499 & 15618 & 9 & Acacia senegal & Sudan, EF & Zhang et al. (1991) \\
\hline TTR 40 & 1506 & 14909 & r $1-7$ & Acacia senegal & Sudan, EO & Zhang et al. (1991) \\
\hline \multicolumn{7}{|l|}{ Sinorhizobium fredii } \\
\hline USDA 191 & 1337 & 8317 & 6 & Soil & China & Scholla \& Elkan (1984) \\
\hline USDA $205^{\mathrm{T}}$ & $2075^{\mathrm{T}}$ & $6217^{\mathrm{T}}$ & - & Glycine $\max$ & China & Scholla \& Elkan (1984) \\
\hline \multicolumn{7}{|l|}{ Sinorhizobium medicae } \\
\hline CC 169 & 1838 & 16582 & - & Medicago rugosa & Australia & Eardly et al. (1990) \\
\hline M 75 & 1808 & 16579 & - & Medicago radiata & Syria & Eardly et al. (1990) \\
\hline M 102 & 1809 & 16580 & - & Medicago truncatula & Syria & Eardly et al. (1990) \\
\hline M 158 & 1837 & 16581 & - & Medicago noeana & Syria & Eardly et al. (1990) \\
\hline \multicolumn{7}{|l|}{ Sinorhizobium meliloti } \\
\hline CC 1002 & - & - & - & NK & NK & B. D. Eardly \\
\hline CC 2013 & - & - & - & Medicago sativa & Australia & Eardly et al. (1990) \\
\hline NZP 4009 & - & 6130 & - & Medicago sativa & Australia & LMG \\
\hline $\begin{array}{l}\text { NZP } 4027^{\mathrm{T}}(=\mathrm{ATCC} \\
\left.9930^{\mathrm{T}}\right)\end{array}$ & - & $6133^{T}$ & - & Medicago sativa & USA & LMG \\
\hline
\end{tabular}


Table 1 (cont.)

\begin{tabular}{|c|c|c|c|c|c|c|}
\hline \multirow[t]{2}{*}{ Strain } & \multicolumn{2}{|c|}{ Strain number } & \multirow[t]{2}{*}{ Cluster* } & \multirow[t]{2}{*}{ Host plant } & \multirow{2}{*}{$\begin{array}{c}\text { Geographical } \\
\text { origin } \dagger\end{array}$} & \multirow[t]{2}{*}{ Reference/source } \\
\hline & НАМВI & LMG & & & & \\
\hline \multicolumn{7}{|c|}{ Sinorhizobium saheli } \\
\hline ORS 600 & 217 & 11864 & - & Sesbania cannabina & Senegal & de Lajudie et al. (1994) \\
\hline ORS $609^{\mathrm{T}}$ & $215^{\mathrm{T}}$ & $7837^{\mathrm{T}}$ & - & Sesbania pachycarpa & Senegal & de Lajudie et al. (1994) \\
\hline TTR 21 & 1495 & 14914 & 14 & Acacia senegal & Sudan, Kh & Zhang et al. (1991) \\
\hline TTR 23 & 1496 & 14928 & 14 & Acacia senegal & Sudan, EF & Zhang et al. (1991) \\
\hline \multicolumn{7}{|c|}{ Sinorhizobium terangae } \\
\hline ORS 51 & 199 & 6464 & - & Sesbania rostrata & Senegal & de Lajudie et al. (1994) \\
\hline ORS $1009^{T}$ & $220^{\mathrm{T}}$ & $7834^{\mathrm{T}}$ & - & Acacia laeta & Senegal & de Lajudie et al. (1994) \\
\hline ORS 1013 & - & 7844 & - & Acacia senegal & Senegal & de Lajudie et al. (1994) \\
\hline EO6 & 248 & 15631 & 12 & Acacia senegal & Sudan, EO & Zhang et al. (1991) \\
\hline $\mathrm{EO} 7$ & 1550 & 14918 & 12 & Acacia senegal & Sudan, EO & Zhang et al. (1991) \\
\hline HAMBI 1392 & - & 15635 & 14 & Prosopis chilensis & Kenya & Zhang et al. (1991) \\
\hline TSO 1 & 1703 & 15627 & 11 & Acacia senegal & Sudan, Te & Zhang et al. (1991) \\
\hline $\operatorname{TTR} 41$ & 1551 & 14931 & 14 & Acacia senegal & Sudan, EF & Zhang et al. (1991) \\
\hline TTR 39 & 1698 & 15630 & 11 & Acacia senegal & Sudan, EF & Zhang et al. (1991) \\
\hline \multicolumn{7}{|l|}{ Rhizobium etli } \\
\hline $\mathrm{CFN} 42^{\mathrm{T}}$ & $1727^{\mathrm{T}}$ & $11937^{\mathrm{T}}$ & - & Phaseolus vulgaris & Mexico & Segovia et al. (1993) \\
\hline \multicolumn{7}{|c|}{ Rhizobium galegae } \\
\hline HAMBI $540^{\mathrm{T}}$ & - & $6214^{\mathrm{T}}$ & - & Galega orientalis & Finland & Lindström (1989) \\
\hline HAMBI 1147 & - & 6215 & - & Galega orientalis & Finland & Lindström (1989) \\
\hline \multicolumn{7}{|c|}{ Rhizobium leguminosarum } \\
\hline ATCC $10004^{\mathrm{T}}$ & - & $8817^{\mathrm{T}}$ & - & Pisum sativum & NK & LMG \\
\hline ATCC 14482 & - & 8819 & - & NK & NK & LMG \\
\hline ATCC 14480 & - & 8820 & - & Trifolium pratens & NK & LMG \\
\hline CNPAF 512 & - & 9505 & - & NK & NK & LMG \\
\hline \multicolumn{7}{|c|}{ Rhizobium tropici } \\
\hline CFN 299 & - & 9517 & - & Phaseolus vulgaris & Brazil & $\begin{array}{l}\text { Martinez-Romero et al. } \\
\text { (1991) }\end{array}$ \\
\hline CIAT $899^{\mathrm{T}}$ & $1163^{\mathrm{T}}$ & $9503^{\mathrm{T}}$ & - & Phaseolus vulgaris & Colombia & $\begin{array}{l}\text { Martinez-Romero et al. } \\
\text { (1991) }\end{array}$ \\
\hline \multicolumn{7}{|c|}{ Mesorhizobium ciceri } \\
\hline UPM-Ca $7^{\mathrm{T}}$ & $1750^{\mathrm{T}}$ & $17150^{\mathrm{T}}$ & - & Cicer arietinum & Spain & Nour et al. (1994) \\
\hline 522 & - & 17149 & - & Cicer arietinum & Russia & Nour et al. (1994) \\
\hline \multicolumn{7}{|c|}{ Mesorhizobium huakuii } \\
\hline CCBAU $2609^{\mathrm{T}}$ & $1674^{\mathrm{T}}$ & $14107^{\mathrm{T}}$ & - & Astragalus sinicus & China & Chen et al. (1991) \\
\hline \multicolumn{7}{|c|}{ Mesorhizobium loti } \\
\hline NZP $2213^{\mathrm{T}}$ & $1129^{\mathrm{T}}$ & $6125^{\mathrm{T}}$ & 5 & Lotus corniculatus & New Zealand & Jarvis et al. (1982) \\
\hline & - & 6126 & - & Lotus maroccanus & Morocco & de Lajudie et al. (1994) \\
\hline \multicolumn{7}{|l|}{$\begin{array}{l}\text { Mesorhizobium } \\
\text { mediterraneum }\end{array}$} \\
\hline $\mathrm{Ca}-36^{\mathrm{T}}$ & - & 17148 & - & Cicer arietinum & Spain & Nour et al. (1995) \\
\hline \multicolumn{7}{|l|}{$\begin{array}{l}\text { Mesorhizobium } \\
\text { plurifarium }\end{array}$} \\
\hline BR 3804 & - & 9970 & - & Chamaecrista ensiformis & Brazil & de Lajudie et al. (1998) \\
\hline INPA $78 \mathrm{~B}$ & 204 & 10056 & - & Leucaena diversifolia & Brazil & de Lajudie et al. (1998) \\
\hline ORS 1001 & 193 & 7836 & - & Acacia senegal & Senegal & de Lajudie et al. (1998) \\
\hline ORS 1030 & 1995 & 11890 & - & Acacia senegal & Senegal & de Lajudie et al. (1998) \\
\hline \multicolumn{7}{|l|}{$\begin{array}{l}\text { Mesorhizobium } \\
\text { tianshanense }\end{array}$} \\
\hline$A-1 B^{T}$ & $1870^{\mathrm{T}}$ & $15767^{\mathrm{T}}$ & - & Glycyrrhiza pallidiflora & China & Chen et al. (1995) \\
\hline 6 & 1956 & 15769 & - & Glycyrrhiza uralensis & China & Chen et al. (1995) \\
\hline $017 \mathrm{~A}$ & - & 15768 & - & Sophora alopecuroides & China & Chen et al. (1995) \\
\hline
\end{tabular}

* Clusters according to Zhang et al. (1991); r, related to.

$\dagger$ The five locations in the Sudan from which strains were isolated are abbreviated as Khartoum (Kh), Tendelti (Te), El Obeid (EO), Kosti (Ko) and El Fau (EF). 


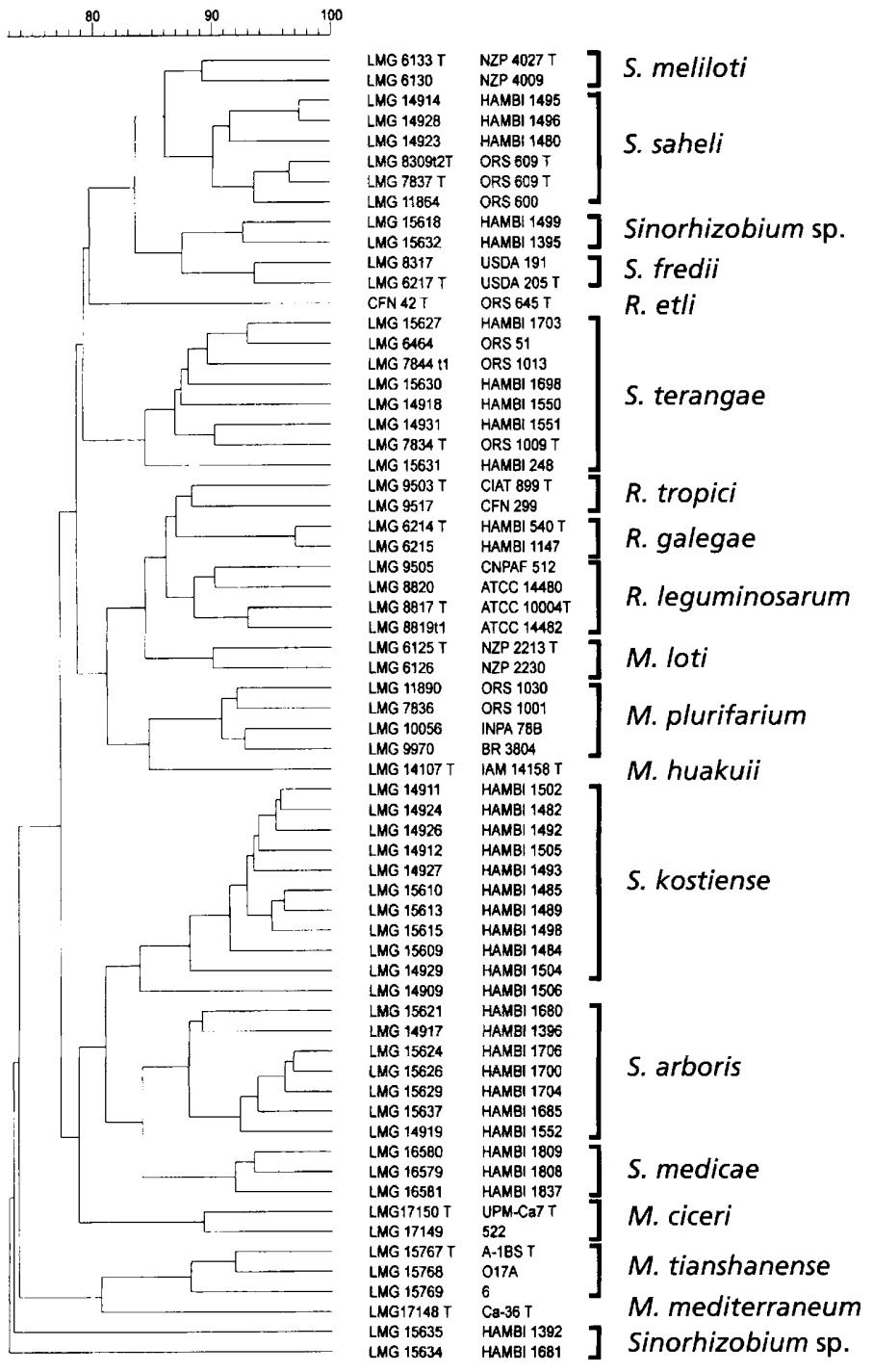

Fig. 1. UPGMA dendrogram of the SDS-PAGE analysis showing the relationships between electrophoretic protein patterns of Sudanese, Kenyan and reference strains of established rhizobial species.

Mesorhizobium ciceri (Nour et al., 1994), Mesorhizobium huakuii (Chen et al., 1991), Mesorhizobium mediterraneum (Nour et al., 1995), Mesorhizobium plurifarium (de Lajudie et al., 1998) and Mesorhizobium tianshanense (Chen et al., 1995). The genus Rhizobium is phylogenetically heterogeneous with two different groups: Rhizobium etli (Segovia et al., 1993), Rhizobium gallicum (Amarger et al., 1997), Rhizobium hainanense (Chen et al., 1997), Rhizobium leguminosarum (Jordan, 1984), Rhizobium mongolense (van Berkum et al., 1998) and Rhizobium tropici (Martinez-Romero et al., 1991) form one rRNA branch and Rhizobium galegae (Lindström, 1989), Rhizobium huautlense (Wang et al., 1998) and Rhizobium giardinii (Amarger et al., 1997) are in a separate branch together with Agrobacterium vitis
(Ophel \& Kerr, 1990) and Agrobacterium biovar 1 (Kersters \& De Ley, 1984).

De Lajudie et al. (1994) have shown that tropical, fastgrowing rhizobia isolated in West Africa are very diverse but are clearly different from previously established species. Sudanese and Kenyan tree nodule isolates showed wide diversity by numerical taxonomy (Zhang et al., 1991) and this was later confirmed by several genotypic anaiyses (Haukka \& Lindström, 1994; Haukka et al., 1996; Nick, 1998; Nick et al., 1999). The previous studies led us to complete the polyphasic taxonomy of the Sudanese and Kenyan strains by using SDS-PAGE of total bacterial proteins, multilocus enzyme electrophoresis (MLEE) and total $16 \mathrm{~S}$ rRNA sequence analysis. On the basis of previous and current results, we propose two new species, Sinorhizobium arboris sp. nov. and Sinorhizobium kostiense sp. nov.

\section{METHODS}

Bacterial strains and growth conditions. Strains used in this study are listed in Table 1. Sudanese and Kenyan strains were isolated from the root nodules of Acacia senegal and Prosopis chilensis (Zhang et al., 1991) and the other strains were representatives of Mesorhizobium, Rhizobium and Sinorhizobium species. All strains were maintained in yeast extract-mannitol (YEM) broth (Lindström et al., 1985) containing $20 \%(\mathrm{v} / \mathrm{v})$ glycerol at $-70^{\circ} \mathrm{C}$ and freeze-dried. For transmission electron microscopy observations, the type strains of $S$. arboris and $S$. kostiense were grown in nonagitated YEM broth, which contained only $1 \mathrm{~g}$ mannitol in $1000 \mathrm{ml}$ medium.

PAGE of total bacterial proteins. SDS-PAGE was performed by using the procedure of Laemmli (1970) with slight modifications, as described previously (Kiredjian et al., 1986; de Lajudie et al., 1994). The normalized densitometric traces of the protein electrophoretic patterns were grouped by numerical analysis, using the GeLCOMPAR 2.2 software package (Applied Maths) (Vauterin \& Vauterin, 1992). The similarity between all pairs of traces was expressed by the Pearson product-moment correlation coefficient $(r)$ converted for convenience to a percentage value (Pot et al., 1989, 1994).

MLEE. Nineteen Sudanese strain and one Kenyan strain were used in MLEE analysis and compared with $S$. saheli, $S$. terangae, two $S$. medicae and four $S$. meliloti strains. The techniques used for starch-gel electrophoresis and selective staining of enzymes have been described previously (Eardly et al., 1990; Eardly, 1994; Selander et al., 1986). The electrophoretic buffer systems and the thirteen enzymes assayed were as follows: Tris/citrate ( $\mathrm{pH} \mathrm{6.7)}$ for 6-phosphogluconate dehydrogenase (6PG), hydroxybutyrate dehydrogenase (HBD), aconitase (ACO) and NAD-malate dehydrogenase (MDH); Tris/citrate ( $\mathrm{pH} 8.0$ ) for phosphoglucose isomerase (PGI), isocitrate dehydrogenase (IDH), glucose6-phosphate dehydrogenase (G6P), leucyl-alanine peptidase (PEP) and leucine aminopeptidase (LAP); and borate (pH 8.2) for indophenol oxidase (IPO), hexokinase (HEX), adenylate kinase (ADK) and phosphoglucomutase (PGM). Distinctive mobility variants (electromorphs) of each enzyme, numbered in order of decreasing anodal mobility, 
Sinorhizobium arboris sp. nov. and S. kostiense sp. nov.

Table 2. Allele profiles at 13 enzyme loci for 18 ETs of Sinorhizobium

\begin{tabular}{|c|c|c|c|c|c|c|c|c|c|c|c|c|c|}
\hline \multirow[t]{2}{*}{ Strain } & \multicolumn{13}{|c|}{ Allele at indicated enzyme locus } \\
\hline & MDH & 6PG & HBD & $\mathrm{ACO}$ & PGI & IDH & G6P & PEP & LAP & IPO & HEX & ADK & PGM \\
\hline \multicolumn{14}{|l|}{ S. arboris } \\
\hline HAMBI 1396 & 3 & 3 & 1 & 1 & 5 & 1 & 3 & 4 & 1 & 2 & 4 & 5 & 3 \\
\hline HAMBI $1552^{\mathrm{T}}, 1680$ & 3 & 3 & 3 & 2 & 4 & 1 & 3 & 3 & 3 & 2 & 2 & 5 & 3 \\
\hline HAMBI 1624 & 3 & 3 & 2 & 2 & 5 & 1 & 3 & 3 & 3 & 2 & 2 & 5 & 3 \\
\hline HAMBI 1685 & 3 & 3 & 4 & 2 & 5 & 1 & 3 & 3 & 4 & 2 & 2 & 5 & 3 \\
\hline HAMBI 1707 & 3 & 3 & 4 & 2 & 4 & 1 & 3 & 3 & 4 & 2 & 2 & 5 & 3 \\
\hline $\begin{array}{l}\text { HAMBI } 1700,1704,1706 \\
\text { S, kostiense }\end{array}$ & 3 & 3 & 4 & 2 & 4 & 1 & 3 & 3 & 5 & 2 & 2 & 5 & 3 \\
\hline \multicolumn{7}{|l|}{ S. kostiense } & 3 & 5 & & & & & \\
\hline HAMBI 1501 & 2 & 1 & 4 & 1 & 4 & 1 & 3 & 5 & 3 & 1 & 1 & $\begin{array}{l}2 \\
1\end{array}$ & $\begin{array}{l}2 \\
2\end{array}$ \\
\hline $\begin{array}{l}\text { HAMBI } 1482,1489^{\mathrm{T}}, 1493 \\
1498,1504\end{array}$ & 2 & 2 & 4 & 3 & 6 & 1 & 3 & 5 & 3 & 2 & 2 & 1 & 3 \\
\hline \multicolumn{14}{|l|}{ Sinorhizobium sp. } \\
\hline HAMBI 1499 & 4 & 4 & 6 & 2 & 5 & 2 & 1 & 3 & 3 & 4 & 3 & 5 & 0 \\
\hline HAMBI 1500,1506 & 1 & 6 & 6 & 2 & 3 & 1 & 4 & 5 & 2 & 2 & 5 & 3 & 1 \\
\hline \multicolumn{14}{|l|}{ S. medicae } \\
\hline M 102 & 3 & 4 & 3 & 2 & 7 & 1 & 2 & 1 & 4 & 1 & 3 & 6 & 6 \\
\hline M 158 & 3 & 5 & 3 & 2 & 7 & 3 & 2 & 1 & 3 & 1 & 3 & 6 & 6 \\
\hline \multicolumn{14}{|l|}{ S. meliloti } \\
\hline ATCC $9930^{\mathrm{T}}, \mathrm{CC} 1002$ & 3 & 6 & 4 & 1 & 2 & 3 & 3 & 3 & 4 & 1 & 5 & 5 & 5 \\
\hline CC 169 & 3 & 7 & 3 & 2 & 7 & 1 & 2 & 1 & 3 & 1 & 3 & 6 & 6 \\
\hline CC 2013 & 3 & 4 & 3 & 1 & 3 & 1 & 2 & 2 & 2 & 1 & 5 & 5 & 7 \\
\hline \multicolumn{14}{|l|}{ S. saheli } \\
\hline ORS $609^{\mathrm{T}}$ & 0 & 8 & 5 & 3 & 1 & 1 & 4 & 5 & 3 & 4 & 1 & 5 & 4 \\
\hline \multicolumn{14}{|l|}{ S. terangae } \\
\hline ORS $1009^{\mathrm{T}}$ & 4 & 7 & 5 & 4 & 5 & 2 & 3 & 4 & 5 & 3 & 3 & 4 & 0 \\
\hline
\end{tabular}

were equated with alleles at the corresponding structural gene locus. Allele profiles, or electrophoretic types (ETs), were equated with multilocus genotypes. The genetic distance between pairs of ETs was estimated as the proportion of loci at which dissimilar alleles (mismatches) occurred and clustering was performed by the unweighted pair group method (Sneath \& Sokal, 1973).

Sequencing of 165 rRNA genes. The 16S rRNA gene sequences of the type strains $S$. arboris HAMBI $1552^{\mathrm{T}}$ and $S$. kostiense HAMBI $1489^{\mathrm{T}}$ were determined. A large fragment of the 16S rRNA of about 1522 bp was amplified by using primers pA (5'-biotin-AGAGTTTGATCCTGGCTCAG $\left.3^{\prime}\right)$ and $\mathrm{pH}^{*}$ (5' AAGGAGGTGATCCAGCCGCA 3') (Edwards et al., 1989). The PCR was carried out in a $100 \mu \mathrm{l}$ reaction volume containing polymerase reaction buffer $\left[10 \mathrm{mM}\right.$ Tris $/ \mathrm{HCl}\left(\mathrm{pH} 8.8\right.$ at $\left.25^{\circ} \mathrm{C}\right), 1.5 \mathrm{mM} \mathrm{MgCl}_{2}, 50 \mathrm{mM}$ $\mathrm{KCl}, 0 \cdot 1 \%$ Triton X-100], $200 \mu \mathrm{M}$ dNTPs (Pharmacia), $1 \mu \mathrm{M}$ of both primers, $2 \mathrm{U}$ DynaZyme II DNA polymerase (Finnzymes) and about $30 \mathrm{ng}$ pure total DNA as template. Amplification was done in an MJ Research MiniCycler with the following temperature profile: initial denaturation at $95^{\circ} \mathrm{C}$ for $3 \mathrm{~min}, 30$ cycles at $94^{\circ} \mathrm{C}$ for $1 \mathrm{~min}, 55^{\circ} \mathrm{C}$ for $1 \mathrm{~min}$ and $72^{\circ} \mathrm{C}$ for $2 \mathrm{~min}$, final extension at $72^{\circ} \mathrm{C}$ for $3 \mathrm{~min}$. The PCR product was sequenced directly by using the solidphase method as described previously (Hultman et al., 1991) with an automated ALF DNA sequencer (Pharmacia) (Ridell et al., 1995). The determined sequences, together with reference sequences obtained from the EMBL database, were aligned by using the PILEUP program in the Wisconsin package of the Genetics Computer Group (GCG). All the sequences used were almost full length and were derived from the type strain wherever possible. A phylogenetic tree was created by the CLUSTAL w 1.7 program (Thompson et al., 1994) using the neighbour-joining method based on a distance matrix with the distance correction calculated by Kimura's two-parameter method. The tree was drawn using the TREEVIEW program (Page, 1996). Identities were calculated using the GAP program in the GCG package.

Morphological and physiological tests. Cell dimensions and morphology were determined under light microscopy. The type of flagellation was determined for the type strains of $S$. arboris and $S$. kostiense by transmission electron microscopy in the electron microscopy laboratory at the Institute of Biotechnology, University of Helsinki.

\section{RESULTS}

\section{SDS-PAGE of total bacterial proteins}

Seven representative strains of $S$. arboris and ten representative strains of $S$. kostiense constituted two main electrophoretic groups, three strains (HAMBI 1480,1495 and 1496) clustered with $S$. saheli and five strains (HAMBI 248, 1550, 1551, 1698 and 1703) with S. terangae. Two strains (HAMBI 1395 and 1499) were related to $S$. fredii while two others (HAMBI 1392 and 1681) had a separate position (Fig. 1). 


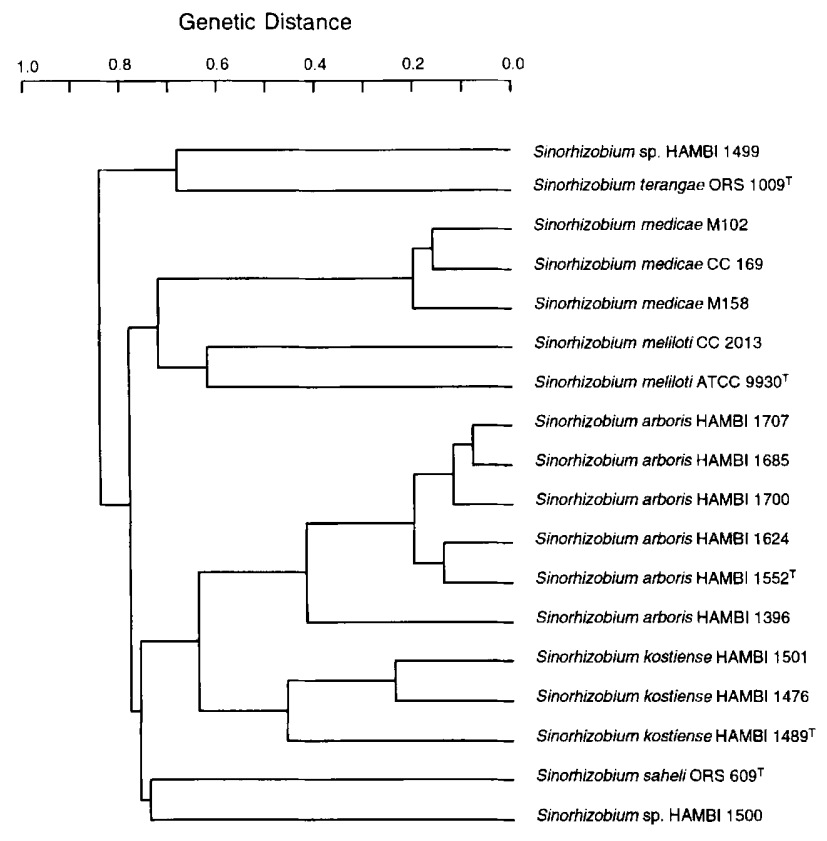

Fig. 2. Genetic relationships among 18 ETs of Sinorhizobium estimated on the basis of electrophoretically detectable allelic variation at 13 loci. A representative isolate is listed for each ET.

\section{MLEE analysis}

Nineteen Sudanese strains and one Kenyan strain were used in MLEE analysis. The $S$. arboris strains revealed six and $S$. kostiense three distinctive multilocus genotypes (ETs). Four of the $S$. arboris and one of the $S$. kostiense ETs were represented by single strains (Table 2 ). Cluster analysis of the ETs grouped nine $S$. arboris and eight $S$. kostiense strains together, and the genetic distances ranged from 0.08 to 0.19 and from 0.23 to $0 \cdot 46$, respectively (Fig. 2). Strains HAMBI 1500 and 1506 gave identical ETs but were clearly different from other strains and species examined, at a genetic distance of 0.78 . The ET of strain HAMBI 1499 was not identical or close to $S$. saheli and was thus in agreement with the result of repetitive-sequence-based (rep)-PCR. S. fredii strains were not included in the MLEE analysis as 16S rDNA PCR-RFLP analysis (Nick, 1998) and protein analysis (data not shown) has shown that the $S$. fredii strains do not form a homogeneous group as the other Sinorhizobium species do and thus need to be studied more thoroughly.

\section{5 rRNA gene sequencing}

The 16S rRNA sequences determined were compared with the 16S rRNA sequences of other members of the $\alpha$-2-subclass of the Proteobacteria available from the EMBL database. Strains HAMBI $1489^{\mathrm{T}}$ and $1552^{\mathrm{T}}$ were found to be closely related but distinct members of the Sinorhizobium lineage (Fig. 3). The levels of sequence identity obtained by using the GAP program are shown in Table 3.

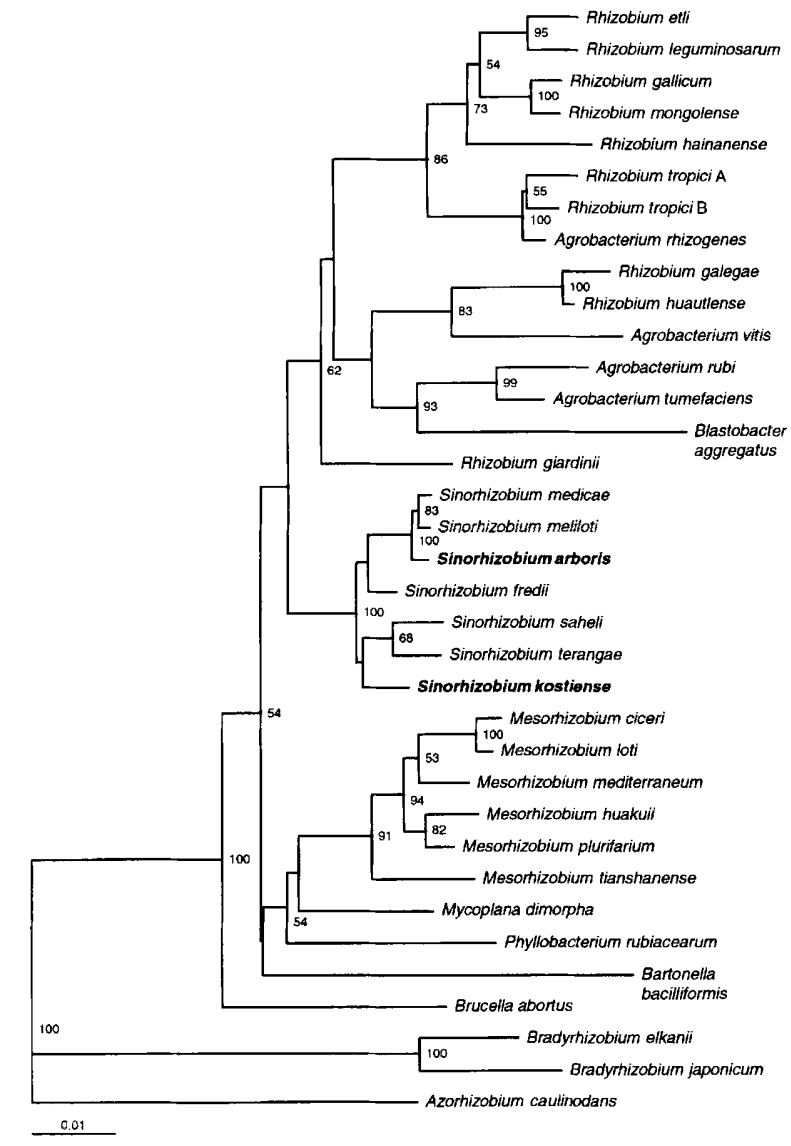

Fig. 3. Phylogenetic tree of rhizobia and some related bacteria in the $\alpha$-subclass of the Proteobacteria. The tree was constructed by the neighbour-joining method from 16S rRNA sequences. Bootstrap probability values greater than $50 \%$ are indicated at the branch-points. Bar, 0.01 substitution per site. The sequences are derived from the type strains wherever possible. The GenBank/EMBL accession numbers used are (from top to bottom): U28916, U29386, U86343, U89816, U71078, X67233, X67234, X67224, X67226, AF025852, X67225, X67228, X67223，X73041，U86344， L39882, X67222, Z78204, X67231, $X 68390, X 68388, Z 78203$, U07934, X67229, L38825, D12797, Y14158, U71079, D12786, D12790, Z11683, X13695, U35000, $\mathrm{X} 66024$ and $\mathrm{X} 67221$.

\section{DISCUSSION}

The relationships between rhizobia isolated from the root nodules of Acacia senegal and Prosopis chilensis trees in Sudan and Kenya were studied by using a polyphasic approach. These rhizobia were first found to be very diverse by numerical taxonomy (Zhang et al., 1991) and were further studied by molecular biological methods including pulsed-field gel electrophoresis (Haukka \& Lindström, 1994), 16S rDNA analyses (Haukka et al., 1996; Nick, 1998), repPCR genomic fingerprinting, dot-blot DNA-DNA hybridization, DNA base composition and DNADNA reassociation analysis (Nick et al., 1999) and cellular fatty acid analysis (S. W. Tighe \& B. D. W. Jarvis, unpublished results). Two of the strains have been found to belong to the new species $M$. plurifarium (de Lajudie et al., 1998). 
Sinorhizobium arboris sp. nov. and S. kostiense sp. nov.

Table 3. 165 rRNA sequence identity levels between sinorhizobia

The values in the lower left part of the table are percentage identities and those in the upper right part of the table are numbers of nucleotide differences observed. The strains used in the comparison are indicated in the left-hand column.

\begin{tabular}{|c|c|c|c|c|c|c|c|}
\hline \multirow[t]{2}{*}{ Strain } & \multicolumn{7}{|c|}{ No. of nucleotide differences/Percentage identity } \\
\hline & 1 & 2 & 3 & 4 & 5 & 6 & 7 \\
\hline 1. S. arboris HAMBI $1552^{\mathrm{T}}$ & - & 17 & 21 & 8 & 8 & 26 & 35 \\
\hline 2. S. fredii USDA $205^{\mathrm{T}}$ & $98 \cdot 7$ & - & 15 & 16 & 14 & 12 & 23 \\
\hline 3. S. kostiense HAMBI $1489^{\mathrm{T}}$ & $98 \cdot 5$ & $99 \cdot 0$ & - & 27 & 25 & 21 & 21 \\
\hline 4. S. medicae A-321 & $99 \cdot 4$ & $98 \cdot 9$ & $98 \cdot 1$ & - & 3 & 27 & 35 \\
\hline 5. S. meliloti NZP $4027^{\mathrm{T}}$ & $99 \cdot 4$ & $99 \cdot 0$ & $98 \cdot 3$ & $99 \cdot 7$ & - & 24 & 35 \\
\hline 6. S. saheli ORS $609^{\mathrm{T}}$ & $98 \cdot 2$ & $99 \cdot 2$ & $98 \cdot 5$ & $98 \cdot 0$ & $98 \cdot 3$ & - & 16 \\
\hline 7. S. terangae ORS $1009^{\mathrm{T}}$ & $97 \cdot 6$ & $98 \cdot 4$ & $98 \cdot 5$ & $97 \cdot 5$ & $97 \cdot 6$ & $98 \cdot 9$ & - \\
\hline
\end{tabular}

The 16S rRNA and cellular fatty acid analyses showed that almost all the Sudanese and Kenyan isolates belong to the genus Sinorhizobium (Haukka et al., 1996; Nick, 1998; S. W. Tighe \& B. D. W. Jarvis, unpublished results). Numerical taxonomy had grouped the majority of these strains in two main clusters, which were phenotypically separate from established species (Zhang et al., 1991), and this finding was confirmed by several genomic analyses (Haukka \& Lindström, 1994; Haukka et al., 1996; Nick, 1998; Nick et al., 1999). To complete the classification of the sinorhizobial isolates, 30 strains were further compared with established rhizobial species by SDS-PAGE of total proteins, 20 strains were studied by MLEE and the full length sequences of the 16S rRNA genes from two strains representing the two main clusters were determined. The results were in good agreement with previous studies and led to the proposal of two new species.

Among the Sudanese and Kenyan strains, we found two strains that belong to $S$. saheli and six strains that belong to $S$. terangae. Strains HAMBI 1495 and 1496 both fell into cluster 14 in the numerical taxonomy analysis (Table 1). They grouped with the Senegalese $S$. saheli strains by dot-blot hybridization, rep-PCR and protein analysis. By 16 S rDNA analyses they were slightly different from the type strain but very close to it (Haukka et al., 1996; Nick, 1998; Nick et al., 1999). In DNA-DNA reassociation analysis, strain HAMBI 1496 was a typical $S$. saheli strain (Nick et al., 1999). Three strains (HAMBI 248, 1550 and 1703) gave similar results to the type strain of $S$. terangae in dotblot hybridization, rep-PCR (Nick et al., 1999), 16S rDNA sequence (Haukka et al., 1996) and PCR-RFLP analyses (Nick, 1998) and protein analysis. Strain HAMBI 1550 was also used in DNA-DNA reassociation analysis and showed very strong homology to $S$. terangae (Nick et al., 1999). Strain HAMBI 1703 behaved differently only in numerical taxonomy, where it was in cluster 11, whereas the other two originated from cluster 12 (Zhang et al., 1991). Strains
HAMBI 1392, 1551 and 1698 clustered with the $S$. terangae type strain in dot-blot hybridization (Nick et al., 1999) and also, in the case of the two latter strains, in protein analysis. They were very closely related to the type strain by $16 \mathrm{~S}$ rDNA analyses and rep-PCR, which probably means that these strains represent the borderlines of the $S$. terangae species, since the DNAbinding level of strain HAMBI 1551 in the S. terangae cluster was not high, although significant (Haukka et al., 1996; Nick, 1998; Nick et al., 1999). In numerical taxonomy, strain HAMBI 1698 belonged to cluster 11 and strains HAMBI 1392 and 1551 to cluster 14 (Zhang et al., 1991). Strain HAMBI 1395 clearly clustered with $S$. terangae in dot-blot hybridization and the short sequenced fragment of the 16S rRNA gene placed it in the $S$. terangae continuum (Haukka et al., 1996; Nick et al., 1999). Numerical taxonomy placed it in cluster 12, together with strains HAMBI 248 and 1550 (Zhang et al., 1991). It had a separate position in SDS-PAGE, and therefore we could not place it with $S$. terangae until the DNA-DNA reassociation results were available. The rest of the sinorhizobial isolates did not group with any of the known species.

In numerical taxonomy, the two main clusters, 8 and 11 , contained 15 and 18 strains, respectively. In addition, three strains were related to cluster 8 . In further analysis by dot-blot hybridization, rep-PCR (Nick et al., 1999) and 16S rDNA PCR-RFLP (Nick, 1998), all the cluster 8 strains except one, which was not studied further, formed a homogeneous group. This group also contained the three strains related to cluster 8 and two strains from cluster 1 and one strain from cluster 9 . We found that phenotypic cluster 11 was more heterogeneous and only eight strains from it formed a distinct group clearly different from the established species. Two other strains, one from cluster 15 and the other related to cluster 18 , also belonged to this second main cluster. The representative strains from both of these clusters also formed separate groups by protein analysis (Fig. 1), MLEE (Fig. 2) and 
DNA-DNA reassociation analysis (Nick et al., 1999). A short sequence $(230 \mathrm{bp})$ of the $16 \mathrm{~S}$ rRNA gene grouped the cluster 11 strains with $S$. medicae (Haukka et al., 1996), but the full-length sequence showed that clusters 8 and 11 represent two new Sinorhizobium species, S. kostiense and S. arboris, respectively (Fig. $3)$. In the dendrogram based on the neighbour-joining method, S. arboris forms a branch with S. medicae and $S$. meliloti, with the two latter species more closely related, whereas $S$. kostiense is by itself. Also, pairwise comparison of sequences by the GAP program showed that the sequence identity was highest between $S$. meliloti and S. medicae $(99 \cdot 7 \%)$.

Eight of the Sudanese and Kenyan isolates did not cluster unambiguously with any of the Sinorhizobium species or clusters 8 or 11 (Table 1). Numerical taxonomy placed five of them in cluster 9 (Zhang et al., 1991), but on further analysis they did not form a separate group. Strains HAMBI 1500 and 1506 were included in the MLEE analysis, since they grouped with $S$. kostiense by $16 \mathrm{~S}$ rDNA PCR-RFLP (Nick, 1998) and with $S$. arboris by rep-PCR (Nick et al., 1999). These strains where not members of any clusters by dot-blot hybridization (Nick et al., 1999). Strain 1506 also had a separate position by SDS-PAGE. MLEE analysis showed that these strains are closely related only to each other. Strain HAMBI 1499 is an interesting isolate; $16 \mathrm{~S}$ rDNA PCR-RFLP grouped it with $S$. saheli, otherwise it remained unclustered. Haukka et al. (1996) found that it has two 16S sequences among its rRNA operons, which were similar to the sequences of strains HAMBI 1393 and 1394. These eight strains clearly belong to Sinorhizobium but additional similar strains have to be studied before they can be assigned to a species.

Among the Sudanese and Kenyan isolates, the two main clusters ( 8 and 11) have been shown to form two distinct groups different from established species. We therefore propose that these strains should be assigned to two new species, Sinorhizobium kostiense sp. nov. and Sinorhizobium arboris sp. nov., respectively.

\section{Description of Sinorhizobium arboris sp. nov.}

Sinorhizobium arboris (ar'bo.ris. L. fem. n. arbor tree; L. fem. gen. n. arboris of the tree).

Short, aerobic, Gram-negative, non-spore-forming rods that are $0.5-0.7 \mu \mathrm{m}$ wide by $1.5-2.0 \mu \mathrm{m}$ long. Motile by means of one or two polar or subpolar flagella. The maximum growth temperature on YEM medium is $41-43{ }^{\circ} \mathrm{C}$. Colonies of most strains on YEM are circular, cream-coloured, semi-translucent and mucilaginous and often spread over an entire plate within 2-4d. A wide range of carbohydrates and amino acids are utilized as sole carbon sources for growth. Physiological and biochemical features typical for this species include growth on $\mathrm{L}-(+)$-isoleucine and tolerance of $3 \%(\mathrm{w} / \mathrm{v}) \mathrm{NaCl}$, heavy metals (but not aluminium) and a wide range of antibiotics. Produces melanin and grows at $\mathrm{pH} \mathrm{8.5.} \mathrm{However,} \mathrm{this} \mathrm{species}$ cannot be identified by biochemical and physiological characters alone. Strains can nodulate Acacia senegal and Prosopis chilensis. At the molecular level, this species can be differentiated by SDS-PAGE whole-cell protein pattern, MLEE, rep-PCR genomic fingerprinting (Nick et al., 1999), RFLP analysis of the amplified 16S rDNA (Nick, 1998), total DNA-DNA hybridization (Nick et al., 1999) and sequencing the of the whole 16S rRNA gene. $S$. arboris can be assigned to the genus Sinorhizobium by cellular fatty acid analysis (S. W. Tighe \& B. D. W. Jarvis, unpublished results). The $\mathrm{G}+\mathrm{C}$ content of the DNA is $60 \cdot 6$ $61.8 \mathrm{~mol} \%$ (Nick et al., 1999). Strain HAMBI $1552^{\mathrm{T}}$ $\left(=\mathrm{LMG} 14919^{\mathrm{T}}\right)$ is the type strain. All the Sinorhizobium arboris strains identified in this paper have been deposited in the Culture Collections of the Department of Applied Chemistry and Microbiology, University of Helsinki, Helsinki, Finland, and the Laboratorium voor Microbiologie, University of Ghent, Ghent, Belgium.

\section{Description of Sinorhizobium kostiense sp. nov.}

Sinorhizobium kostiense (kos.ti.en'se. L. neut. adj. kostiense pertaining to Kosti, the region in Sudan from which the majority of the organisms were isolated).

Short, aerobic, Gram-negative, non-spore-forming rods that are $0.5-0.7 \mu \mathrm{m}$ wide by $1.5-2.0 \mu \mathrm{m}$ long. Motile by means of one or two polar or subpolar flagella. The maximum growth temperature of the majority of the strains on YEM medium is $38-40^{\circ} \mathrm{C}$. Colonies of most strains on YEM are circular, creamcoloured, semi-translucent and mucilaginous and often spread over an entire plate within 2-4 d. A narrow range of carbohydrates and amino acids are utilized as sole carbon sources for growth. Physiological and biochemical features typical for this species include tolerance of only $1 \%(\mathrm{w} / \mathrm{v}) \mathrm{NaCl}$ and sensitivity to heavy metals (except copper and lead) and to a wide range of antibiotics. Produces melanin but does not grow at pH 5.5 or $8 \cdot 5$. However, this species cannot be identified by biochemical and physiological characters alone. Strains can nodulate Acacia senegal and Prosopis chilensis. At the molecular level, this species can be differentiated by SDS-PAGE whole-cell protein pattern, MLEE, rep-PCR genomic fingerprinting (Nick et al., 1999), RFLP analysis of amplified 16S rDNA (Nick, 1998), total DNA-DNA hybridization (Nick et al., 1999) and sequencing of the whole 16S rRNA gene. $S$. kostiense can be assigned to the genus Sinorhizobium by cellular fatty acid analysis (S. W. Tighe \& B. D. W. Jarvis, unpublished results). The $\mathrm{G}+\mathrm{C}$ content of the DNA is $57.9-61.6 \mathrm{~mol} \%$ (Nick et al., 1999). Strain HAMBI $1489^{\mathrm{T}}$ (= LMG $\left.15613^{\mathrm{T}}\right)$ is the type strain. All the Sinorhizobium kostiense strains identified in this paper have been deposited in the Culture Collections of the Department of Applied Chemistry and Microbiology, University of Helsinki, Helsinki, Finland, and the Laboratorium voor Microbiologie, University of Ghent, Ghent, Belgium. 
Sinorhizobium arboris sp. nov. and S. kostiense sp. nov.

\section{ACKNOWLEDGEMENTS}

We thank Sirpa Tiikkainen, Kari Lounatmaa and EevaLiisa Paunonen for helping us with the transmission electron microscopy. This work was supported by a grant from the University of Helsinki and by the Commission of the European Communities (STD3 Programme contract no. TS3-CT93-0232). M.G. is indebted to the Fund of Scientific Research - Flanders (Belgium), for research and personal grants.

\section{REFERENCES}

Amarger, N., Macheret, v. \& Laguerre, G. (1997). Rhizobium gallicum sp. nov. and Rhizobium giardinii sp. nov., from Phaseolus vulgaris nodules. Int J Syst Bacteriol 47, 996-1006.

van Berkum, P., Beyene, D., Bao, G., Campbell, T. A. \& Eardly, B. D. (1998). Rhizobium mongolense sp. nov. is one of three rhizobial genotypes identified which nodulate and form nitrogen-fixing symbioses with Medicago ruthenica [(L.) Ledebour]. Int J Syst Bacteriol 48, 13-22.

Chen, W. X., Li, G. S., Qi, Y. L., Wang, E. T., Yuan, H. L. \& Li, J. L. (1991). Rhizobium huakuii sp. nov. isolated from the root nodules of Astragalus sinicus. Int J Syst Bacteriol 41, 275-280.

Chen, W. X., Wang, E. T., Wang, S., Li, Y., Chen, X. \& Li, Y. (1995). Characteristics of Rhizobium tianshanense sp. nov., a moderately and slowly growing root nodule bacterium isolated from an arid saline environment in Xinjiang, People's Republic of China. Int J Syst Bacteriol 45, 153-159.

Chen, W.-X., Tan, Z.-Y., Gao, J.-L., Li, Y. \& Wang, E.-T. (1997). Rhizobium hainanense sp. nov., isolated from tropical legumes. Int J Syst Bacteriol 47, 870-873.

Dreyfus, B., Garcia, J. L. \& Gillis, M. (1988). Characterization of Azorhizobium caulinodans gen. nov., sp. nov., a stem-nodulating nitrogen-fixing bacterium isolated from Sesbania rostrata. Int $J$ Syst Bacteriol 38, 89-98.

Eardly, B. D. (1994). Multilocus enzyme electrophoresis methods for the analysis of bacterial population genetic structure. In Methods of Soil Analysis, Part 2. Microbiological and Biochemical Properties, pp. 557-573. Edited by R. W. Weaver, J. S. Angle \& P. J. Bottomley. Madison, WI: Soil Science Society of America.

Eardly, B. D., Materon, L. A., Smith, N. H., Johnson, D. A., Rumbaugh, M. D. \& Selander, R. K. (1990). Genetic structure of natural populations of the nitrogen-fixing bacterium Rhizobium meliloti. Appl Environ Microbiol 56, 187-194.

Edwards, U., Rogall, T., Blöcker, H., Emde, M. \& Böttger, E. C. (1989). Isolation and direct complete nucleotide determination of entire genes. Characterization of a gene coding for $16 \mathrm{~S}$ ribosomal RNA. Nucleic Acids Res 17, 7843-7853.

Haukka, K. \& Lindström, K. (1994). Pulsed-field gel electrophoresis for genotypic comparison of Rhizobium bacteria that nodulate leguminous trees. FEMS Microbiol Lett 119, 215--220.

Haukka, K., Lindström, K. \& Young, J. P. W. (1996). Diversity of partial 16S rRNA sequences among and within strains of African rhizobia isolated from Acacia and Prosopis. Syst Appl Microbiol 19, 352-359.

Hultman, T., Bergh, S., Moks, T. \& Uhlén, M. (1991). Bidirectional solid-phase sequencing of in vitro-amplified plasmid DNA. BioTechniques 10, 84-93.

Jarvis, B. D. W., Pankhurst, C. E. \& Patel, J. J. (1982). Rhizobium loti, a new species of legume root nodule bacteria. Int $J$ Syst Bacteriol 32, 378-380.
Jarvis, B. D. W., van Berkum, P., Chen, W. X., Nour, S. M., Fernandez, M. P., Cleyet-Marel, J. C. \& Gillis, M. (1997). Transfer of Rhizobium loti, Rhizobium huakuit, Rhizobium ciceri, Rhizobium mediterraneum, and Rhizobium tianshanense to Mesorhizobium gen. nov. Int J Syst Bacteriol 47, 895-898.

Jordan, D. C. (1984). Family III. Rhizobiaceae Conn 1938. In Bergey's Manual of Systematic Bacteriology, vol. 1, pp. 234-256. Edited by N. R. Krieg \& J. G. Holt. Baltimore: Williams \& Wilkins.

Kersters, K. \& De Ley, J. (1984). Genus III. Agrobacterium Conn 1942. In Bergey's Manual of Systematic Bacteriology, vol. 1, pp. 244-254. Edited by N. R. Krieg \& J. G. Holt. Baltimore: Williams \& Wilkins.

Kiredjian, M., Holmes, B., Kersters, K., Guilvout, I. \& De Ley, J. (1986). Alcaligenes piechaudii, a new species from human clinical specimens and the environment. Int $J$ Syst Bacteriol 36, 282-287.

Kuykendall, L. D., Saxena, B., Devine, T. E. \& Udell, S. E. (1992). Genetic diversity in Bradyrhizobium japonicum Jordan 1982 and a proposal for Bradyrhizobium elkanii sp. nov. Can J Microbiol 38, 501-505.

Laemmli, U. K. (1970). Cleavage of structural proteins during the assembly of the head of bacteriophage T4. Nature 227, 680-685.

de Lajudie, P., Willems, A., Pot, B. \& 7 other authors (1994). Polyphasic taxonomy of rhizobia: emendation of the genus Sinorhizobium and description of Sinorhizobium meliloti comb. nov., Sinorhizobium saheli sp. nov., and Sinorhizobium teranga sp. nov. Int J Syst Bacteriol 44, 715-733.

de Lajudie, P., Willems, A., Nick, G. \& 9 other authors (1998). Characterization of tropical tree rhizobia and description of Mesorhizobium plurifarium sp. nov. Int $J$ Syst Bacteriol 48, 369-382.

Lindström, K. (1989). Rhizobium galegae, a new species of legume root nodule bacteria. Int $J$ Syst Bacteriol 39, 365-367.

Lindström, K., Sarsa, M., Polkunen, J. \& Kansanen, P. (1985). Symbiotic nitrogen fixation of Rhizobium (Galega) in acid soils and its survival in soil under acid and cold stress. Plant Soil 87, 293-302.

Martínez-Romero, E., Segovia, L., Mercante, F. M., Franco, A. A., Graham, P. \& Pardo, M. A. (1991). Rhizobium tropici, a novel species nodulating Phaseolus vulgaris L. beans and Leucaena sp. trees. Int J Syst Bacteriol 41, 417-426.

Nick, G. (1998). Polyphasic taxonomy of rhizobia isolated from tropical tree legumes. $\mathrm{PhD}$ thesis. Dissertationes Biocentri Viikki Universitatis Helsingiensis, Department of Applied Chemistry and Microbiology, University of Helsinki.

Nick, G., Jussila, M., Hoste, B., Niemi, M., Kaijalainen, S., de Lajudie, P., Gillis, M., de Bruijn, F. J. \& Lindström, K. (1999). Rhizobia isolated from the root nodules of tropical leguminous trees characterized using DNA-DNA dot-blot hybridisation and rep-PCR. Syst Appl Microbiol (in press).

Nour, S. M., Fernandez, M. P., Normand, P. \& Cleyet-Marel, J.-C. (1994). Rhizobium ciceri sp. nov., consisting of strains that nodulate chickpeas (Cicer arietinum L.). Int $J$ Syst Bacteriol 44, $511-522$

Nour, S. M., Cleyet-Marel, J.-C., Normand, P. \& Fernandez, M. P. (1995). Genomic heterogeneity of strains nodulating chickpeas (Cicer arietinum L.) and description of Rhizobium mediterraneum sp. nov. Int $J$ Syst Bacteriol 45, 640-648.

Ophel, K. \& Kerr, A. (1990). Agrobacterium vitis sp. nov. for strains of Agrobacterium biovar 3 from grapevines. Int $J$ Syst Bacteriol 40, 236-241. 
Page, R. D. M. (1996). TreeView: an application to display phylogenetic trees on personal computers. Comput Appl Biosci 12, 357-358.

Pot, B., Gillis, M., Hoste, B., Van De Velde, A., Bekaert, F., Kersters, K. \& De Ley, J. (1989). Intra- and intergeneric relationships of the genus Oceanospirillum. Int $J$ Syst Bacteriol 39, 23-34.

Pot, B., Vandamme, P. \& Kersters, K. (1994). Analysis of electrophoretic whole organism protein fingerprints. In Chemical Methods in Prokaryotic Systematics, pp. 493-521. Edited by M. Goodfellow \& T. O'Donnell. Chichester: Wiley.

Ridell, J., Siitonen, A., Paulin, L., Lindroos, O., Korkeala, H. \& Albert, M. J. (1995). Characterization of Hafnia alvei by biochemical tests, random amplified polymorphic DNA PCR, and partial sequencing of $16 \mathrm{~S}$ rRNA gene. J Clin Microbiol 33, 2372-2376.

Rome, S., Fernandez, M. P., Brunel, B., Normand, P. \& CleyetMarel, J.-C. (1996). Sinorhizobium medicae sp. nov., isolated from annual Medicago spp. Int J Syst Bacteriol 46, 972--980.

Scholla, M. H. \& Elkan, G. H. (1984). Rhizobium fredii sp. nov., a fast-growing species that effectively nodulates soybeans. Int $J$ Syst Bacteriol 34, 484-486.

Segovia, L., Young, J.P. W. \& Martínez-Romero, E. (1993). Reclassification of American Rhizobium leguminosarum biovar phaseoli type I strains as Rhizobium etli sp. nov. Int $J$ Syst Bacteriol 43, 374-377.
Selander, R. K., Caugant, D. A., Ochman, H., Musser, J. M., Gilmour, M. N. \& Whittam, T. S. (1986). Methods of multilocus enzyme electrophoresis for bacterial population genetics and systematics. Appl Environ Microbiol 51, 873-884.

Sneath, P. H. A. \& Sokal, R. R. (1973). Numerical Taxonomy. San Francisco: W. H. Freeman.

Thompson, J. D., Higgins, D. G. \& Gibson, T. J. (1994). CLUSTAL $\mathrm{W}$ : improving the sensitivity of progressive multiple sequence alignment through sequence weighting, position-specific gap penalties and weight matrix choice. Nucleic Acids Res 22, 4673-4680.

Vauterin, L. \& Vauterin, V. (1992). Computer-aided objective comparison of electrophoresis patterns for grouping and identification of microorganisms. Eur Microbiol 1, 37-41.

Wang, E. T., van Berkum, P., Beyene, D., Sui, X. H., Dorado, O., Chen, W. X. \& Martínez-Romero, E. (1998). Rhizobium huautlense sp. nov., a symbiont of Sesbania herbacea that has a close phylogenetic relationship with Rhizobium galegae. Int $J$ Syst Bacteriol 48, 687-699.

Xu, L. M., Ge, C., Cui, Z., Li, J. \& Fan, H. (1995). Bradyrhizobium liaoningense $\mathrm{sp}$. nov., isolated from the root nodules of soybeans. Int J Syst Bacteriol 45, 706-711.

Zhang, X., Harper, R., Karsisto, M. \& Lindström, K. (1991). Diversity of Rhizobium bacteria isolated from the root nodules of leguminous trees. Int J Syst Bacteriol 41, 104-113. 